\title{
The Relationship Between NATO and Russia Through the Prism of Mutual Cooperation and Confrontation
}

\author{
Elena Temelkovska-Anevska, Assistant Professor \\ Faculty of Law, University “St. Kliment Ohridski”- Bitola, Macedonia \\ doi: 10.19044/esj.2017.v13n13p153 URL:http://dx.doi.org/10.19044/esj.2017.v13n13p153
}

\begin{abstract}
The aim of this paper is to analyze the relationship between NATO and Russia, to explain the historical background of their relationship, to detect challenges of their relation and to specify the potential future areas of cooperation. Some of their policy objectives are overlapping, so the cooperation enables them to accomplish these important objectives.

Although NATO became the most powerful military international organization in the world, over the years, it confronts strategic challenges and dilemmas divided in two groups: existing and new. These challenges included Russia's aspiration for dominance, developments in Afghanistan, terrorism as an international risk, the Arab Spring, China as a global player and turn of the United States foreign policy toward the Asia-pacific region.

This paper will focus on one of these challenges: Russia's ambitions for dominance and its influence on NATO-Russia relationship, identifying specific areas and issues of cooperation and confrontation. In the foreseeable future, NATO needs to focus on challenges and developments of a strategic importance for the Alliance, such as the innovative efforts for enhanced relationships, limited missions, operations and a realistic combination of solutions that can serve the principles and values of all NATO allies, including the most influential.
\end{abstract}

Keywords: NATO, Russia, relationship, cooperation, confrontation, security

"Great powers don't join coalitions, they create coalitions.
Russia considers itself a great power.”
Dmitry Olegovich Rogozin,
Russia’s Ambassador to NATO, March 2009

\section{Introduction}

The origins of the North Atlantic Treaty Organization (further in the text: NATO, the Alliance) are often connected with the need of its members 
to balance the rising power of the Soviet Union after the Second World War. This is referred to as its main raison d'être. On the other hand, the 1980s symbolizes the end of Soviet imperial rule that did not lead to end of NATO. Consequently, NATO is the most successful and long-lasting military alliance in history, the key instrument for defense of its members against Soviet subversion or attack and a key mechanism in speeding up the disintegration of the Soviet Union.

The persistence of NATO can be found in three main factors. First, the creation of a new Alliance strategic concept adopted at the end of 1991 just days before the collapse of the Soviet Union. It was a reflection of the need for protection against an uncertain future. This model or concept noted one of the four fundamental security tasks of NATO - the necessity to "preserve the strategic balance in Europe" (North Atlantic Treaty Organization 1991: paragraph 21).

Second, as a military alliance, NATO was formed to recognize threats or to balance the countervailing power of the Soviet Union. However, NATO has always meant more than providing this sense of balance: according to the Preamble to the North Atlantic Treaty of 1949 its member states were determined "to safeguard the freedom, common heritage and civilization of their peoples, founded on the principles of democracy, individual liberty and the rule of law". Over time, it developed from alliance for military protection of its member states into a viable institutional expression of the transatlantic community of states united by their determination to defend the western values that defined them.

Third, the need for change and adaptation of its structure and mission to its new environment reshaped the organization, both military and politically. In this process, the Alliance transformed into a politico-military entity. The military adjustment has led to a more flexible authority structure with ability for rapid deployment of armed forces. The political adaptation meant that the Alliance needed new missions in order to maintain its importance - from peacekeeping missions to non-proliferation of weapons of massive destruction (Brookings Institution 2001: 1-3).

In the begging of the $21^{\text {st }}$ century there were three feasible concepts of NATO: an alliance of collective defense, an alliance of collective security and an alliance of collective interests. The first purpose defined NATO as a military alliance whose aim was to provide protection from Russia. The second purpose described the organization as an institution whose main aim was to promote the western values and to enhance stability and security throughout Europe, but also to keep the sense of a community that holds both sides of the Atlantic together. And finally, the last purpose was a vision of an organization that defends its member states against any kind of common security threats. 
Over the years, NATO showed great capability for quick adaptation to new circumstances and conditions in the changing global strategic landscape, but this ability led to insufficient unity among its member states, and consequently, an inadequate political determination to provide NATO with the necessary qualifications for an ambitious schedule. Thus, the Alliance needs a sense for flexibility and openness.

\section{Historical background and current status of the mutual relations between NATO and Russia}

The official beginning of the relationship between NATO and Russia was the inaugural session of the North Atlantic Cooperation Council (NACC) founded in December 1991. In 1997 The Council was renamed in EuroAtlantic Partnership Council (EAPC). The Council was created with an aim to encourage a new relationship with the countries of Central and Eastern Europe. In order to build up and individual relation with the Alliance, Russia joined the Partnership for Peace Programme (PfP) in 1994, which deepened their relationship. PfP was created to offer bilateral cooperation on many issues and to oversee the security cooperation and peacekeeping operations between both entities. It means practical participation in NATO's peacekeeping operations in Bosnia and Kosovo (SFOR and KFOR). In the 1990s the Russia's contribution in the peacekeeping operations (IFOR and SFOR in Bosnia and Herzegovina) was the biggest compared to other nonNATO contributors.

In the 1990s, Russia had a few reasons to be reserved with regards to PfP and NATO's enlargement. Russian position on NATO enlargement toward East was clear: the classical geopolitical view of Russia was connected with the necessity to have influence in the region and to create a strong bond with the countries in the region. The other reason is the fact that Russia has identical reputation as other post-Soviet countries. This was not in accordance with Russia's interpretation of its own geopolitical position in the world. Furthermore, the level of significance of PfP for Russia was different than for countries from Central and East Europe, because the only practical use of this program for these countries was to reshape their military forces in accordance with NATO standards.

In March 1999, former Soviet satellite states Poland, Hungary and the Czech Republic joined NATO. In order to balance these memberships, in 1997 (the period when the accession talks for these three countries began) NATO and Russia agreed the "Founding Act on Mutual Relations, Cooperation and Security”. This Act gave Russia the capability to be part of the Permanent Joint Council (PJC) and to be at the same table as members of NATO (in the " $19+1$ " format). The cooperation continued and in 1998 Russia established a diplomatic mission to NATO. However, one year later 
their relations were strained by the Alliance's intervention in Yugoslavia, when Russia withdrew its representatives from NATO headquarters (Foxall 2014: 4-5).

The cooperation between NATO and Russia has started more intensively in 2002, on the basis of NATO-Russia Council (NRC). The new format of cooperation replaced the previous " $19+1$ " ("NATO+1") format under the former Permanent Joint Council (PJC). One of the major benefits of the NATO-Russia Council of 20 was the opportunity for Russia to be part of the discussions within NATO from the beginning. Both sides were ambitious to cooperate within NRC as equal partners on a broad range of security matters in the Euro-Atlantic region and in accordance with the Foundation Act of NRC (consensus-building, cooperation, consultation, joint decision and united action for the member states of NATO and Russia). On the other hand, the Foundation Act of NRC noted that cooperation between NATO member states and Russia will increase in areas including antiterrorism, non-proliferation, crisis management, arms control-building measures, confidence-building measures, search and rescue at sea, theatre missile defense, military-to-military cooperation, and civil emergencies. Although real activities have been restrained, there were areas where actual results were achieved, such as ISAF mission in Afghanistan (Padrtovả, 2012: 24-26).

The terrorist attacks in the USA on 11 September 2001 made it clear that security threats, such as terrorism, instability in Central Asia and weapons of mass destruction are common for both entities. One year later, with Rome Declaration the NATO-Russia Council (NRC) was established in which NATO and Russia members sit as equals ("27 members", instead of " $26+1$ ") and make a decisions by consensus. The meetings of the NRC were temporarily suspended in 2008 during the war between Russia and Georgia. Although there were certain areas in which NATO stopped cooperation with Russia, the cooperation continued on issues with common interest, such as fight against terrorism and counter-narcotics.

The first meeting of NATO-Russia Council in December 2009 was an attempt to revive their relationship by agreeing to launch a "Joint Review of $21^{\text {st }}$ century Common Security Challenges”. Their cooperation continued over the years: the NRC revised its 2004 "Action Plan on Terrorism" in 2011; the next year, General Knud Bartels ${ }^{10}$ visited Russia to improve military-to-military cooperation; and in 2013, Anders Fogh Rasmussen met with the Russian Foreign Minister Sergey Lavrov to discuss possible methods to upgrade the dialogue on the issue of missile defense.

${ }^{10}$ General Knud Bartels is a retired Danish general. He served as a Danish Chief of Defence between 2009 and 2011. He was Chairman of the NATO Military Committee from 2011 to 2015. 
There are two different conceptions in their mutual relations: NATO is not willing to allow Russia to have a veto over NATO's decisions, while Russia sees itself as a world power that deserves a full voice in security issues in Europe. However, it is more than just a question of power, it is an issue of purpose. The intention of NATO is to create stability and security in Eastern Europe. Meanwhile, Russia is responsible for creating conflicts and instability in Ukraine, Georgia and Moldova in order to expand its influence in the region and prevent further influence by NATO. Russia made an objection to NATO's policy of expansion of its influence toward Central and Eastern Europe. On the other hand, NATO believed that its ambition to enlarge stability, prosperity and peace in Europe will be recognized and accepted by Russia as an advantage to all, instead as a threat to Russia (Goldgeier 2010: 10).

The current status of their relations can be derived from their security cultures and different perceptions on European security and what threatens it. Russian approach preserves a strictly geopolitical understanding of security, while NATO maintain on its wider interpretation of security.

Their policy formulations are characterized by their mutual perceptions. According to NATO, there is no need for Russia to consider NATO as a threat and NATO do not consider Russia as a threat to its member states and their population (Rasmussen 2012). However, there was negative rhetoric on the Russian side: Russia perceives NATO as a military bloc hostile to its interests.

Current relations between NATO and Russia are characterized by noticeable differences and complications. Their relationship is contradictory by nature, with areas and issues of close cooperation as a counterbalance of its ideological confrontation, distrust and reciprocal criticism.

The relationship between these two entities can be analyzed by dividing it into four phases, each with specific features and qualities.

The first phase covered the period from 1991 to 1998. It was characterized by creating a regulatory and legal basis for bilateral relations: the process of signing strategic documents that would formalize their cooperation. This was a period when the Russia-NATO Permanent Joint Council began operation. The leaders from both sides demonstrated the necessary political will necessary for creating a path of military and political cooperation. NATO and Russia accomplished mutual peacekeeping operations in Bosnia and Herzegovina.

The second phase covered a one year period - from 1999 to 2000. It was characterized by significant decline in mutual relations. The reason for this downturn was Russia's reaction to the NATO operation in Kosovo, which -according to Russia- was performed without strict mandate of the UN Security Council and with infringement of international law. Their 
cooperation in peacekeeping operations in Kosovo was not always successful (Alexeev 2014:15).

The third phase, from 2001 to 2004, was associated with Vladimir Putin coming to power, as a president. As paradoxical as it may seem, this phase brought a new wave of cooperation, related to common threats and challenges. Putin took several steps toward NATO and the West, giving support to the USA in the war on terrorism and joining the anti-terrorism coalition. In 2001, in Moscow, NATO opened the NATO Military Liaison Mission and the NATO Information Center. The next year, the Russia-NATO Council was created which coordinated the bilateral cooperation and moved it to a higher level. This progress from the Permanent Joint Council of " $19+1$ " to the Russia-NATO Council of " 20 " - according to former NATO Secretary-General George Robertson - was not a question of arithmetic or mathematic, but of chemistry (Czulda, 2013: 180). This third phase was the most positive and successful period in the history of their relation.

The fourth phase, covered the period from 2005 to 2012. It was the longest and most complex period in terms of its structure. Their mutual relations came across many compromises and challenges during this phase, but still in the sense of "pragmatic cooperation and strategic competition". The Russia-Georgia war in 2008 was a great challenge in their bilateral relations. The ISAF mission, too. This was a period with visible military cooperation and poor political tone. Some unfavorable events, such as the socalled "color revolutions" in several former Soviet republics, were considered by Russia as a direct cause of interference of USA and Western Europe. The accession of Baltic states in NATO and open enlargement policy towards Ukraine and Georgia provoked irritation in Moscow. The antiballistic program and its implementation also sparked criticism from Russia. These NATO, USA and EU programs in the post-Soviet space were recognized as interference in the most sensitive area of Russian foreign policy. Russia supposed that supporting the USA in the anti-terrorism war and promoting a policy of political closeness would maintain the status quo in this zone of crucial interest for Russia. But, the reality was completely different. Russia-Georgia war in 2008 can be considered as an explicit reaction to the pressure in previous years. These events did not indicate any kind of return to confrontation between NATO and Russia. The history of mutual relations between NATO and Russia shows that alongside confrontations there are a number of successful joint operations in military, political and civilian areas. This has helped strengthen trust between NATO and Russia (Alexeev 2014: 15-16).

The relationship between NATO and Russia is one of the most significant relations that affect the Euro-Atlantic security. Their relationship faces cooperation in number of issues, such as International Security 
Assistance Force mission (ISAF), counter-terrorism, counter-narcotics, nuclear weapons, and crisis management. Although the cooperation, they faces a lot of challenges, such as NATO enlargement and its “open door" policy, and missile defense in Europe, which can lead to potential disagreements and can have a negative influence on their mutual cooperation in practice.

\section{Issues and areas of cooperation and confrontation Issues of cooperation}

NATO and Russia face common threats of radical Islamists in Afghanistan and share common interests in stabilization of the region. One of the examples of successful cooperation between NATO and Russia is ISAF. It has been a keystone in NATO-Russia cooperation. This mission started in March 2008 and was based on strategic interests of Russia to allow land transit through Russia of non-military freight from NATO, its member states and non-NATO ISAF contributors, in support of the ISAF and according to the United Nations Security Council Resolution 1386. The problem occurred when this political decision in such extremely sensitive field of cooperation needed to be presented to the Russian public and domestic political representatives. The connection of this decision to UN Resolution was a perfect explanation for the public, because any kind of refusal to fulfill the Resolution would lead to a major decrease in Russia's reputation as a reliable partner. Moreover, the Russian Government adopted a decree on $25^{\text {th }}$ June 2012 which extended ISAF transit options to engage combine transportation, by rail, road and air. The transit was implemented by Russian transport companies through the Vostochny airport in the city of Ulyanovsk. Russia gained economic profit from the transport of around 160 thousand containers and 50 thousand wheeled vehicles. It meant around 800 million USD. Moreover, the country profited from selling helicopters Mi-17, military equipment and ammunition to NATO (Felbab-Brown, 2012).

Russia was deriving benefits from ISAF mission in terms of stability and security. NATO's efforts were welcomed by Russia, especially in the area of stabilizing the southern boundaries of Russia and NATO's attempts to control the region. It means that without the presence of NATO in the Central Asia region, the armed forces of Russia would have been responsible for maintaining the security and stabilization. In addition, ISAF protects Russia from infiltration of extremists or spread-out of their powers to the Russia's key region of influence. Therefore, ISAF was a great opportunity for Russia to fulfill its direct interests for maintaining stability and security in the region of Central Asia (Padrtovả, 2012: 27-28).

NATO is facing a number of old and new challenges that occupy the interests of its member states. Russia's aspiration for dominance is one of the 
constant challenges for NATO. The Alliance has to find ways to balance between its main objectives - cooperative security and collective defense and creating a partnership with Russia.

Russia is a difficult partner - its interest to keep a harsh attitude from time to time and to prevent the conflict resolution in Eastern Europe can constantly deteriorate or worsen the relation between two sides (Monaghan 2011).

In 2013, the Russian Foreign Minister, Sergey Lavrov confirmed the readiness of Russia to find models of interaction with NATO. He focused on two main factors for security in the Euro-Atlantic region: the ability of Russia and NATO to neutralize the risks from beyond the region and the level of readiness on both sides to jointly solve the problems that they inherited from the past. The relations of Russia with NATO should be based on trust, equality and consideration of each other's interests. Lavrov emphasized that NATO should not take the path of appropriation of functions assigned to the UN Security Council or to attempt to justify force projection in any region of the world at the discretion of NATO. Lavrov concluded that the nature of their mutual cooperation will depend on the evolution of NATO, degree of readiness of its members to ensure supremacy of international law, consideration of other's interests, respect the principle of equal and indivisible of security (Lavrov 2013).

Afghanistan will also remain a challenge. The predictions say that NATO will play an important role in this country until 2024 during the political transformation phase. Military engagement requires civilian responsibility. A set of reasonable decisions and a legitimate operation have transformed NATO into a guardian of a complex state-building process. NATO's member states have had different reactions, some of them did not want to be a part of NATO's missions and operations, and other focused on special operations and unmanned warfare (Riecke 2012: 3-5).

\section{Issues of confrontation and disagreement}

Apart from the practical cooperation in Afghanistan, there are number of contentious issues on which the positions of NATO and Russia differ. These areas are connected with issues that concern strategic interests of both sides. Among them are the issues of the war in Georgia and the recognition of Abkhazia and South Ossetia. The second issue is NATO's enlargement policy, mainly, the possibility for membership of Ukraine and Georgia. The third issue covers the collaboration on missile defense in Europe. Despite these three major areas of disagreement, there are problematic issues in other areas - one of them is the Syria crisis, where the geopolitical interests of both sides slightly differed due to their strategic interests in the region of the Middle East. 
The first issue critical to their mutual relations was the Georgian war and the position of the Alliance towards it. The war caused a gap in their relationship, which was on the lowest level in a decade and was slowly improving in the next two years. Their relations were officially re-established in 2010, when Russia was invited by NATO to the Lisbon Summit. This point of their mutual relations was caused by the official NATO's position towards the war, stating that "Alliance expressed particular concern over Russia's disproportionate military action which was incompatible with Russia's peacekeeping role in the breakaway regions of South Ossetia and Abkhazia” (NATO 2012).

Another issue of disagreement was NATO's “door open” policy and its commitment to future enlargement of the Alliance, especially the membership of Georgia and Ukraine. The Russian position was supported by a strong group of member states within the Alliance, such as Germany and France who see Georgia's accession as unacceptable. Contrary, NATO confirmed many times that Georgia is a real candidate for accession. ${ }^{11}$

One of the reasons was the active contribution of this country to the ISAF as the second largest troop contributor from all non-NATO countries (NATO 2012). Although, the Dialogue on Ukraine's membership started in 2005, its accession was not realistic in the near future. The key reason for this situation, at that time, was that Ukraine was not following the NATO membership as a goal in the foreign policy. The second reason was low public support of the Ukrainians to the membership. According to Gallup (2010), almost $40 \%$ of the Ukrainians see NATO as a threat, than as a protection (17\%). Eventually, the change may occur in future, but both memberships are only theoretical opportunities at the moment.

NATO's policy toward Ukrainian and Georgian membership is clear. They are allowed to develop closer connections to NATO according to their aspiration and progress, until they are ready for membership. However, each of them has major obstacles to the membership. Ukraine struggles with internal political challenges and Ukrainians remain skeptical that joining the Alliance is a worthy ambition. In the meantime, the Russia-Georgia war in 2008 guaranteed that their territorial dispute will not be solved anytime soon. At NATO's Summit in 2009, the Alliance's leaders announced that "NATO's door will remain open to all European democracies which share the values of [the] Alliance; which are willing and able to assume the responsibilities and obligations of membership; and whose inclusion can contribute to common security and stability" (NATO 2009). Those are the three criteria which refer to the enlargement process. The first two were

11 This NATO position was confirmed on the NATO Summits in Bucharest (2008), in Lisbon (2010) and in Chicago (2012). 
standard criteria during the post-Cold War period, and the third one represents the additional difficulty for Ukraine and Georgia related to their disputes with Russia. In July 2009 during its official visit to Moscow, the US president Barack Obama stated that 'a majority of the population of the candidate country must support membership’ (The White House, 2009). This was considered as an additional criterion, clearly and undoubtedly directed to Ukraine (Goldgeier 2010: 11-13).

Traditionally, the question of NATO enlargement evokes a negative reaction in Russia. This Russian attitude is based in something more profound than the nature of its power. There are both rational and emotional causes of this perception. First, Russia is a continental state and for that reason has always wanted to secure itself by surrounding with friendly states and allies. Nowadays, it is very difficult for Russian political tradition to ignore NATO enlargement towards East. The NATO expansion has a powerful negative psychological effect to Russian strategic thinking. Second, NATO enlargement with former republics of the Soviet Union implies a decline of international status among Russian politicians and political elites, but also among Russian people. Aside from the emotional causes of this opinion, most Russian military strategists and political experts view NATO enlargement "as a violation of the strategic balance of forces in Europe" (Alexeev, 2014:17). Russia has a few significant questions regarding NATO expansion on East, such as: how will NATO expansion ease Russia's security concerns; how will enlargement of NATO with former Soviet republics enhance security in the region; and what type of threats accelerate NATO to new wave of enlargement and accepting new members?

However, this kind of attitude cannot lead to a conclusion that NATO is considered as a threat to Russia. Russia and its officials, very frequently express their disapproving opinions and negative rhetoric to debate NATO's policies, which may create an image of a constant external threat, but in practice, Russia is prepared for cooperation with NATO in the areas of terrorism, Afghanistan, and counter-drug trafficking.

Although, Russia does not have any disagreements with NATO member states that could theoretically lead to conflict of interests in the foreseeable future, many Russians view NATO as an old-fashioned alliance from $20^{\text {th }}$ century which expands unrealistically in order to make Europe stronger in the international security ambiance, although its rhetoric about the necessity of basic modifications in the character of security threats in the region of Eurasia, which require new means.

The third disagreement was about missile defense in Europe that was considered as a catalyst for their mutual relations. There were two possible scenarios: it could either lead to cooperation in a pragmatic manner or to worsening of their relations. According to Dmitri Trenin, the "missile 
defense can be either a game changer or a game breaker”. As a game changer it can lead to real cooperation in foreseeable future, but as a game breaker it can be a linkage toward the past with a possible danger of going one step backward (Trenin 2010). The last couple of years there were efforts on the both sides to make a progress on this issue, in particular through the activity of NRC in this area (Chicago Summit Declaration 2012).

Russia's plan on the missile defense in Europe was to participate as an equal partner on the basis of transparency and reciprocity and to have an equal participation in decision-making process. Therefore, Russia requires "more transparency" from the Alliance about missile defense plans and abilities in order to guarantee them that it poses no threat.

Russia made a proposal to NATO to create the so-called 'sectoral' missile defense. Each country will have a responsibility to ensure the missile defense protection for its own region in Europe. These conditions were inappropriate for NATO (Padrtovả, 2012: 28-30). If these two separate systems that work independently of each other were developed by NATO, Russia would have tried to lock them, in order to secure its own right of veto. This opposes the provisions of the NATO-Russia Founding Act, which excludes any right of veto over the operations of the other or any kind of limitation on the rights of Russia or NATO to autonomous decision-making and action (Sherr 2011).

This type of collaboration requires trust that does not exist. The future progress of their collaboration in practice will help to enhance mutual confidence and improve their relations. On the other hand, if Russia ignores the opportunity to cooperate with the Alliance on common missile defense in Europe, the USA and NATO will surely produce a new system without Russia. This is an extraordinary challenge for Russia, because the situation of status quo is not suitable option that can be maintained easily (Trenin 2012).

A major issue for Europe is whether Russia will remain to the provisions of the OSCE Final Act from Helsinki, particularly, the prohibition on changing borders by force. In August 2008 Russia broke that treaty when it used force in order to support the secession of South Ossetia and Abkhazia from Georgia. This Russia's action confirmed the limits of the OSCE's (Organization for Security and Cooperation in Europe) capacity to provide mechanisms for dispute resolution. It confirmed the failure of the NRC to take consequential action in the dispute and showed NATO's limits in defending and maintaining the Helsinki Final Act principles on non-NATO territory. This was another example where NATO was not capable to manage threats on its own.

The NRC demonstrated readiness to increase the number of mutual practical exercises and training operations to confront problems such as nuclear safety and terrorism. The Europeans and their commitments are vital: 
if they can manage to accomplish their obligations, then NATO could recommend a joint NATO-Russia reaction to confront urgent situations throughout the region. In this case, NATO should assure Russia that these efforts are purely defensive and that transparency is crucial (Goldgeier 2010: 12).

In the last two years, namely, at the beginning of 2015, the nuclear strategy of Russia provoked a great concern in NATO structures. Russia's strategy in the field of nuclear weapons indicated a tendency for decreasing the intensity of using nuclear forces (Reuters 2015). In response to this kind of transformation, NATO member states must also update their nuclear arsenal. In that connotation, the Defense Secretary of Great Britain, Sir Michael Fallon, assumed that Russia may repeat strategies and methods used in Ukraine in Baltic countries that are members of the NATO (The Guardian 2015). Similarly, the defense minister of Norway, Ine E. Soreide, noted that the intentions of Russia were uncertain (The New York Time 2015). Tensions between NATO and Russia increased in November 2015 when Russian warplane crushed in the airspace of Turkey while on a mission in Syria. Turkey toppled the warplane because it supposedly violated the airspace of Turkey, but Russian officials disagreed with the assumption that the warplane entered the Turkish airspace. Another reason for disagreement was the formal invitation of Montenegro to join NATO in December 2015, which led to expected reaction on the side of Russia that it would suspend cooperation with Montenegro.

In 2016, NATO-Russia relations were characterized by intense and constant disagreements. Launching the European missile defense shield by NATO in May 2016 confirmed that NATO and Russia had no constructive agenda to follow. Russia repeated its position that launching this system would weaken the Russian security and would create 'direct threat' to regional and global security (The New York Times 2016).

In July 2016, Warsaw was a host city of the NATO Summit. The Alliance agreed to strengthen Baltic States and eastern Poland against the Russia's threats, by moving military troops in eastern Poland and Baltic states by early 2017 and enhancing the sea and air security in these allies. According to the Warsaw Summit Communiqué, the purpose of this decision was to demonstrate, once again, "the solidarity, determination and ability to act" by activating an "immediate allied response to any aggression" and suspending all kinds of cooperation with Russia - military and civilian, while demonstrating openness to political dialogue (Warsaw Summit Communiqué 2016). Heads of State and Government at the Summit declared that Russia with its assistance for the regime and its military presence in Syria increased the security challenges for NATO allies. For that reason, NATO leaders decided to support Ukraine and to make its security and defense bodies 
effective and responsible. As predicted, the Summit briefly deteriorated the confrontation, because the agenda included issues traditionally criticized by Russia, such as progress in missile defense, the enlargement process, and finalizing the strategic rearrangement started at the Summit in Wales (Klein and Major, 2015).

Shortly after the Summit, the NATO-Russia Council held its meeting, where Russia expressed concerns over NATO military activities in the region of the Black sea. In July 2016, Russia stated that a new weapon system (surface-to-air) would be positioned in Crimea, strengthening Russia's antiaccess abilities around the Crimean peninsula.

Some Russian authors, such as Alexey Fenenko, Fyodor Lukyanov, Igor Yurgens and Dmirty V. Suslov, analyze the disagreements between Russia and NATO in the shadow of Russia-USA relationship.

According to Fenenko (2016), the hostility between Russia and the USA changed after the collapse of the Soviet Union. He determines two aspects of their mutual relation that irritated Washington. The first one is related with the fact that Moscow had preserved the nuclear potential of the former Soviet Union. Consequently, Russia was the only country that has the military capability to start a war against the USA, due to their similar military power. Second, Russia is a permanent member of the UN Security Council and may block US's actions or make them illegitimate. Despite declared strategic partnership between them, the USA intentions were to destroy Russia's strategic capabilities to a safe level for the USA. The economic recovery of Russia would lead to modernization of its military industry, which was not in a best interest of the USA. Fenenko warned about the possible Washington's actions against Russia, such as sanctions against individual Russian companies or discovering a new human rights issue. It was clear that economic battle against Russia could benefit the USA only with full support of the EU. Russia was concerned with the international law reform initiated by the USA, which generated two principles: forced removal of the leaders of sovereign states with their accusation by an international tribunal and forced disarmament of dangerous regimes, as seen by Washington, by eliminating their weapons of mass destruction.

Lukyanov (2014, pp. 9-24) argues that President Putin will try to use the size and power of the USA against it in a form of geopolitical aikido. Putin seems unwilling to stimulate instability in countries like Afghanistan, because it can have a spillover effect on Russia. As an alternative, Putin will try to bond countries troubled by the USA behavior in order to create a coalition that can be able to press for a repair of global institutions that would weaken Western and American dominance. Lukyanov suggests Beijing as a key player in this scenario, together with any other government dissatisfied with the overall consequences of globalization in political, economic, social 
and cultural sphere. Russia could accelerate the process by developing a new ideology based on justice and equality among nations. He concludes that it may be a better solution for Moscow to end its cooperation with Washington in the area of security, rather than its active antagonism to the USA. For instance, Lukyanov stated that President Putin saved the USA from another war or embarrassing retreat in the Middle East by assisting and agreement on Syria's chemical weapons. In the meantime, U.S. international expectations have increased to such a level that they are hard to ignore or fulfill. The USA needs Russian help in order to avoid future humiliation in the Middle East.

Yurgens (2014, pp. 39-49) evaluates the challenges to Russia's economy entailed in any confrontation, adding that any extended crisis would be more influenced by Russian neoconservatives, whom he describes as 'foreign policy hawks' who are very pleased with the economic isolation from the West. Russian policy is likely to become less economically rational, as Russia's economic integration with the USA and the EU will weaken the importance of Russian politics and decision-making. Therefore, Russia will have to look for new markets or to become economically dependent upon China if the relations with the West continue to be tense.

Suslov (2013, p.7) elaborates three components of the defective and negative relationship between Russia and the USA. The first component is related with the lack of a new agenda in their mutual relations, which would correspond to the circumstances and challenges in the changing international environment, including managing nuclear multipolarity, the strategic dialogue on the Asia pacific and China, the development of the Far east and Siberia, and Afghanistan and the region of Central Asia. The second component includes the strategic deterrence and counterbalancing philosophy which interfere with the military and defense sector. The last component represents the backward nature of the relationship between Russia and USA in the areas of international and regional security and foreign policy, especially the role of arms control. According to Suslov (2013, pp. 14-18) there are two possible scenarios for the future relationship between these two countries: a selective and pragmatic cooperation or comprehensive deterioration and a new crisis.

\section{Ukraine crisis and annexation of the Crimean peninsula - influence and consequences}

The additional complex issue which can be included in the previously explained set of issues of disagreement is the Russian invasion and annexation of the Crimean peninsula in March 2014 which lead to deepening the actual crisis between both entities. In the beginning of September 2014 was held NATO Summit in Newport, South Wales. It was expected that the 
Summit will review the ISAF mission that ended in late 2014. Instead, the Summit offered a response to Russia's actions in Ukraine. (Foxall 2014: 3).

The response of the Alliance was as expected: reaffirmation of its commitments to defend the allies from Central and Eastern Europe, strengthening the cooperation with Ukraine, and threatening Russia by suspending all practical collaboration. It was a second time NATO had done so since Russian invasion of Georgia in 2008. However, extended sphere of influence of Russia was not the only important concern facing NATO. There were other concerns too, such as, the rise of Islamic State in the Middle East and the partial success of NATO's operation in Libya and Afghanistan. Nevertheless, the Ukraine crisis remained the main factor amongst all, because it tested the preparedness of the Alliance to answer such a disturbing question.

In late 2013 began the Ukraine crisis with demonstrations on Kyiv’s Maidan. The invasion of Ukraine induced fear that its hostility could endangered the territorial integrity of NATO's eastern members while creating issues about NATO's capability to deter Russian aggression in its neighborhood and beyond. Russia made obstructions to US policy in Syria by arming the Assad regime and providing diplomatic cover for its assaults on US backed rebels. The relationship between Russia and the USA turned into a crisis that can undermine future opportunities for cooperation and threaten to destabilize the transatlantic community. In 2009, when US President Barack Obama first entered office, he initiated the "reset" policy towards Russia which enabled these two countries to cooperate on a broad variety of issues, from development and trade to arms reduction and counterterrorism. During the presidency of Dmitry Medvedev, Russia redirected its focus from power competition to pragmatic cooperation with the USA. The accession of Russia to the WTO in 2012 and the assistance of Russia in implementing sanctions against Iran were signals that their mutual relations, although very challenging, offered meaningful opportunities for pragmatic cooperation (Smith and Twardowski, 2017).

In late February 2014 when pro-Russian forces took control over Crimea, it developed into an international crisis. The first explanation from Russia was that the forces were local units for self-defense, but later acknowledged that they were Russian military units without official marks for their military rank. NATO criticized military intensification in the peninsula, expressing "grave concern” about the Russian Parliament's decision from 1 March, which gave President Vladimir Putin permission to use Russia's military forces on the Ukrainian territory. The Sevastopol authorities, on 11 March proclaimed peninsula's independence from Ukraine and 10 days later the Crimea was incorporated into Russia. The U.S. answer to annexation of Crimea was expelling Russia from the G8, imposing 
economic and political sanctions and military measures in order to reassure the eastern allies. The Obama administration promised to increase the US military presence (training, exercise and rotational presence) in eastern European countries (Smith and Twardowski, 2017).

In March 2014, the Information and Press Department of the Russian Ministry of Foreign Affairs commented with disagreement to the statement of the NATO Council, in which Russia was accused of military escalation in Crimea and violation of the principles of international law. In the statement, the Russian Ministry of Foreign Affairs confirmed that the existing threats to the sovereignty and territorial integrity of Ukraine are caused exclusively by the internal political crisis ${ }^{12}$.

NATO's response to Russian aggression has been primarily rhetorical. The Alliance urged Russia to adhere to its duties, responsibilities and obligations in accordance to international law, to comply with international law, and to participate in a dialogue with Kyiv in order to find political and diplomatic solution for solving the crisis. However, the Alliance took some actions, too. In April, NATO postponed the military and civilian cooperation with Russia and a few months later, in July, the European Union ended all future arms sales to Russia. NATO has strengthened its commitment to defend countries from Central and Eastern Europe by initiating a number of activities, such as air defense and surveillance, maritime deployments and military exercises. Despite these initiatives, the Alliance had to demonstrate its readiness and capacity to defend its interests and its allies in Eastern Europe. The Ukraine's crisis sharpened the concerns about Russia's strategic and geopolitical ambitions in the region of Eastern Europe (Foxall 2014: 6-7). Some Russian, European and US analysts argued that the ignorance of the West for the Russian security needs forced Russia to respond militarily, blaming NATO and EU for depriving Russia of its security space in Eastern Europe, especially regarding the expansion of NATO on East and the "close relationship" between Ukraine and EU association agreement (Smith and Twardowski, 2017).

The crisis in Ukraine was a 'game changer' for the Alliance, because until that moment the security priorities of NATO had been focused on terrorism and unsuccessful states. The Ukraine crisis demonstrated the need for re-assessment of the threats and military capabilities and development of a strategy for addressing unconventional forms of warfare. For the first time

\footnotetext{
${ }^{12}$ Comment by the Information and Press Department of the Russian Ministry of Foreign Affairs regarding the question put by the mass media about the statement of the NATO Council on the situation in Ukraine. 3 March 2014. http://www.mid.ru/en/foreign_policy/news//asset_publisher/cKNonkJE02Bw/content/id/72562
} 
since the end of the Cold War, NATO had an obligation to focus on the defense of Eastern Europe against Russia.

The context of mutual relations between Russia and NATO has changed - Russia has gone from being a 'strategic partner' to a hostile aggressor. NATO has been trying to develop new strategies in order to respond to Russia's use of unconventional warfare. Russia assumed that the absence of political will on the side of NATO was the reason why NATO did not respond to aggression.

Their relationship was recovered after the Russo-Georgian War in 2008. It was a reflection of a consensus within NATO that a strong, durable, cooperative and trusting relationship with Russia is necessary for transatlantic security. There are still a number of issues and areas of shared interests, including: non-proliferation of weapons of massive destruction, anti-terrorism, arms control, and security in the Arctic. However, after the Ukraine crisis it was obvious that NATO need to provide protection against future Russian aggression in Eastern Europe.

\section{Conclusion}

More recently, both NATO and Russia appear to be determined in taking advantages of the practical effects of their relation. More than two decades since the end of the Cold War, the attitudes of NATO and Russia from that period have continued to affect their political views. Competition, distrust and political disagreements along with the different approaches about the future of European security are easily noticeable in relations between NATO and Russia.

Moreover, the perception of NATO in Russia is more simplified: the USA equates to NATO. The feeling of distrust and suspicions about other's motives are still present and despite the improvements in their relations, the level of cooperation is still somewhere in the middle between antagonism in the past and the desired future cooperation. The ISAF confirmed that Russia can play a significant role in NATO's missions and that both sides are capable to work together in issues and areas of common interests. Their cooperation is expected in common security challenges in order to ensure the security in the Euro-Atlantic zone.

There is a certain possibility for continuous cooperation in the areas of shared interests including crisis management, nuclear weapons issues, non-proliferation of weapons for mass destruction, search and rescue at sea, arms control, defense industrial cooperation, defense strategy, defense reform, Cooperative Air-space Initiative, civil emergencies, and increasing public knowledge of the NRC, especially in the areas of fight against terrorism, counter-piracy and counter-narcotics, which are the most developed areas of cooperation between both entities. 
As was mentioned previously in this paper, the cooperation between NATO and Russia on the issue of missile defense in Europe has the ability to either move their mutual relations to a higher level or to end up in an impasse. This issue has little technical obstacles, it is mostly the misconception and political and strategic concerns of Russia that can block the cooperation on missile defense. The second scenario will not mean another Cold War, but will produce deeper enmity and isolation of Russia.

Over recent years a number of events, including the deficiency of conventional threats, the confusing post-Cold War role, and decrease of the defense expenses amongst its members contributed to a sense that NATO may be an inappropriate and irrelevant organization. Despite its intervention in Libya and counter-terrorism operations after terrorist attacks in the USA on 11 September 2001, NATO has faced an identity crisis. However, invasion of Georgia, annexation of Crimean peninsula, and destabilization of Ukraine gave NATO a new aspiration. Russia was a NATO partner for many years and a key country for global and transatlantic security. For that reason, Russia was a powerful reminder that one of the crucial priorities of NATO is the security of its member states. These events were lessons for NATO. The annexation of Crimea demonstrated the ineffectiveness of NATO's conventional deterrence and effectiveness of Russian unconventional warfare tactics.

In 2014, Anders Fogh Rasmussen in his speech in Chatham House on occasion of the Wales Summit of NATO (in September 2014), emphasized that "Russia's aggression against Ukraine was an attempt to rewrite international rules and recreate a sphere of influence." He underlined three key issues as a response to overall threats: finalizing the mission in Afghanistan; strengthening the concept of collective defense; and continuous global engagement. The second key question for the Wales Summit was how to strengthen NATO's collective defense. Rasmussen focuses on the necessity of multi-dimensional alliance instead of one-dimensional: the Alliance has to demonstrate readiness to respond and act rapidly in today's unpredictable security environment. For that reason, NATO developed the Alliance Readiness Action Plan, which includes the best techniques to deploy NATO's forces for deterrence and defense. The third big issue was about global engagement of the Alliance. In order to provide effective, coherent and timely support, NATO developed a new Defense Capacity Building Initiative, which will focus on the support in the areas of military training, defense reform and defense planning.

NATO should confirm its policy of accessibility to European countries that meet its criteria in order to retain the cohesion of Article $\mathrm{X}$ and to avoid creating unwanted divisions in Europe. The low speed pathway to 
membership for Ukraine and Georgia minimizes the uneasiness of Russia and generate better options for cooperation with Russia.

During the past two decades, NATO and Russia learned to cooperate on a variety of issues. They have solved complex situations and conflicts and rise above their essential differences. This positive experience can be used to intensify and strengthen cooperation and to explore new compromises on future disputes. Despite all motives for optimism, the most challenging issues in their relationship require specific caution.

As a conclusion, although there is some progress in their relationship, we cannot assume that cooperation in the areas of common interests will have an increasing effect toward cooperation in other fields or that this cooperation can exclude their conflicting approaches on a number of issues in the future. Hence, good intentions and good will are the most important factors for positive bilateral relations. This is a contention that history has confirmed to be mostly correct.

\section{References:}

1. Alexeev D. (2014). Resetting relations with Russia. Journal of European Security and Defence Issues “Per Concordiam”. George C. Marshall European Center for Security Studies. Vol.4, issue 2.

2. Brookings Institution. (2001). NATO's purpose after the Cold War. NATO in the $21^{\text {st }}$ century. Final, 19 March 2001. (pp.1-3). Available at: https://www.brookings.edu/wpcontent/uploads/2016/06/reportch1.pdf [accessed 10 January 2017]

3. Chicago Summit Declaration. (2012). Available at: http://www.chicagonato.org/chicago-summit-declaration-news40.php [accessed 10 March 2017]

4. Czulda R. (2013). Russia-NATO: Towards a Partnership or a New Cold War? In Czulda R. \& Łos R., (Eds.). NATO towards the challenges of a contemporary world. (pp.165-182). Warsaw-Lodz: International Relations Research Institute and University of Lodz.

5. Felbab-Brown, V. (2012). Stuck in the Mud: The Logistics of Getting Out of Afghanistan. Foreign Affairs. Available at:

6. http://www.foreignaffairs.com/articles/137785/vanda-felbabbrown/stuck-in-the-mud?cid=nlcthis_week_on_foreignaffairs_co071912-stuck_in_the_mud_3-071912 [accessed 12 March 2017]

7. Fenenko, A. (2016). Worse than during the Cold War: the conflict potential of U.S-Russia relations. Russia in global affairs. No.2/2016. Available at:

8. http://eng.globalaffairs.ru/number/Worse-Than-During-the-ColdWar-18069 [accessed 12 April 2017] 
9. Foxall, A. (2014). A fateful Summit: The future of NATO's relationship with Russia. Policy Paper No.1. Russia Studies Centre: The Henry Jackson Society.

10. Gallup. 2010. Ukrainians Likely Support Move Away From NATO. Available at: http://www.gallup.com/poll/127094/ukrainians-likelysupport-move-away-nato.aspx [accessed 15 March 2016]

11. Goldgeier,M.J. 2010. The future of NATO. Council Special Report No.51. Council on Foreign Relations. International Institutions and Global Governance Program.

12. Kleine M. \& Major C. (2015). Perspectives for NATO-Russia relations. Forms of confrontations dominate - but dialogue not excluded. SWP Comments. German Institute for International and Security Affairs. November 2015. Available at:

13. https://www.swpberlin.org/fileadmin/contents/products/comments/20 15C49_kle_mjr.pdf [accessed 10 January 2017]

14. Lavrov, S. (2013). Russia-France, Russia-Europe: partnership horizons. Magazine "Russia in Global Affairs”. 23 May 2013. Avaialbale at: http://www.mid.ru/en/foreign_policy/rso//asset_publisher/0vP3hQoCPRg5/content/id/108766 [accessed 12 April 2017]

15. Lukyanov, F. (2014). Russia's asymmetrical response: global aikido. In Saunders, Paul J. (ed.). Costs of a New Cold War: the U.S. - Russia confrontation over Ukraine. Center for the National Interest. Washington, DC.

16. Monaghan, A. (2011). Limited Partnership: Despite Fundamental Disagreements, NATO Seeks to Pull Russia Closer. Internationale Politik-Global Edition 12, (May-June). (pp. 22-26).

17. NATO. (2012). NATO's relations with Georgia. Available at: http://www.nato.int/cps/en/natolive/topics_38988.htm [accessed 10 January 2017]

18. NATO Summit. (2009). Declaration on Alliance Security. Available at:

19. http://www.nato.int/cps/en/natolive/news_52838.htm?mode=pressrele ase [accessed 10 January 2017]

20. North Atlantic Treaty Organization. (1991). The Alliance's Strategic concept. North Atlantic Council, Rome, 7-8 November 1991. (para.21).

21. Padrtovả, B. (2012). NATO-Russia relations. In Ondrejcsảk, R. \& Górka-Winter, B. (Eds.). NATO’s future partnerships. BratislavaWarsaw: Centre for European and North Atlantic Affairs, Polish Institute of International Affairs. Available at: 
http:/cenaa.org/analysis/nato-russia-relations/ [accessed 5 February 2017]

22. Rasmussen, F.A. (2012). Statement by NATO Secretary General at the press point following the NATO-Russia Council meeting in Foreign Ministers session. 19 April 2012. Available at:

23. http://www.nato.int/cps/en/natolive/opinions_86234.htm [accessed 10 February 2017]

24. Rasmussen, F.A. (2014). The future of NATO: A strong Alliance in an unpredictable world. Chatham House: The Royal Institute of International Affairs.

25. Reuters. (2015). Insight-Russia's nuclear strategy raises concerns in NATO. 4 February 2015. Available at: http://uk.reuters.com/article/uk-ukraine-crisis-russia-nuclear-insightidUKKBN0L825A20150204 [accessed 10 February 2017]

26. Riecke, H. (2012). Focused Engagement: NATO's political ambitions in a changing strategic context. Conference Report and Expert Papers "Smart defence and the future of NATO: can the Alliance meet the challenges of the twenty-first century?” Chicago, Illinois: Chicago Council on Global Affairs.

27. RT. (2014). Putin acknowledges Russian military serviceman were in Crimea. Available at: https://www.rt.com/news/crimea-defenserussian-soldiers-108/ [accessed 20 February 2017]

28. Russian Ministry of Foreign Affairs. (2014). Comment by the Information and Press Department of the Russian Ministry of Foreign Affairs regarding the question put by the mass media about the statement of the NATO Council on the situation in Ukraine. 3 March 2014. Available at: http://www.mid.ru/en/foreign_policy/news//asset_publisher/cKNonkJE02Bw/content/id/72562 [accessed 12 April 2017]

29. Sherr, J. (2011). NATO and Russia: doomed to disappointment? NATO Review. Available at:

30. http://www.nato.int/docu/review/2011/NATO_Russia/Disappointmen t/EN/index.htm [accessed 27 February 2017]

31. Smith, J. and Twardowski, A. (2017). The future of U.S.-Russia relations. Center for a new American Security. 11 January 2017. Available at: https://www.cnas.org/publications/reports/the-future-ofu-s-russia-relations [accessed 12 April 2017]

32. Suslov, D. (2013). The US-Russia relations after the "reset": pragmatism or a new confrontation? Basic Research Program. Working Papers. Series: International relations. WP BRP 04/IR/2013. National Research University Higher School of Economics (HSE). 
33. The Guardian. (2015). Russia a threat to Baltic States after the Ukraine conflict, warns Michael Fallon. 19 February 2015. Available at: https://www.theguardian.com/politics/2015/feb/19/russia-a-threatto-balticstates-after-ukraine-conflict-warns-michael-fallon [accessed 15 January 2017]

34. The New York Times. (2015). Norway reverts to Cold War mode as Russian Air Patrol Spike. 1 April 2015. Available at: https://www.nytimes.com/2015/04/02/world/europe/a-newlyassertive-russia-jolts-norways-air-defenses-into-action.html?_r=1 [accessed 25 February 2017]

35. The New York Times. (2016). Russia calls new U.S. missile defence system a 'direct threat'. 12 May 2016. Available at: https://www.nytimes.com/2016/05/13/world/europe/russia-nato-usromania-missile-defense.html?_r=0 [accessed 30 January 2017]

36. The White House, Office of the Press Secretary. (2009). Remarks by the President at the New Economic School Graduation. Gostinny Dvor, Moscow, Russia. July 7 2009. Available at: https://www.whitehouse.gov/the-press-office/remarks-president-neweconomic-school-graduation [accessed 2 March 2017]

37. Trenin, D. (2011). NATO and Russia today: interview with Dmitri Trenin. NATO Review.

38. Available

http://www.nato.int/docu/review/2011/NATO_Russia/Trenininterview/EN/index.htm [accessed 1 February 2017]

39. Warsaw Summit Communiqué. (2016). Paragraphs 11 and 40. July 2016. Available at: http://www.nato.int/cps/en/natohq/official_texts_133169.htm [accessed 30 January 2017]

40. Yurgens, I. (2014). Targeted sanctions with an unclear target. In Saunders, Paul J. (ed.). Costs of a New Cold War: the U.S. - Russia confrontation over Ukraine. Center for the National Interest. Washington, DC. 